\title{
Serotonin and cognitive flexibility: neuroimaging studies into the effect of acute tryptophan depletion in healthy volunteers
}

Citation for published version (APA):

Evers, E. A. T., van der Veen, F. M., Fekkes, D., \& Jolles, J. (2007). Serotonin and cognitive flexibility: neuroimaging studies into the effect of acute tryptophan depletion in healthy volunteers. Current Medicinal Chemistry, 14(28), 2989-95. https://doi.org/10.2174/092986707782794032

Document status and date:

Published: 01/01/2007

DOI:

10.2174/092986707782794032

Document Version:

Publisher's PDF, also known as Version of record

Please check the document version of this publication:

- A submitted manuscript is the version of the article upon submission and before peer-review. There can be important differences between the submitted version and the official published version of record.

People interested in the research are advised to contact the author for the final version of the publication, or visit the DOI to the publisher's website.

- The final author version and the galley proof are versions of the publication after peer review.

- The final published version features the final layout of the paper including the volume, issue and page numbers.

Link to publication

\footnotetext{
General rights rights.

- You may freely distribute the URL identifying the publication in the public portal. please follow below link for the End User Agreement:

www.umlib.nl/taverne-license

Take down policy

If you believe that this document breaches copyright please contact us at:

repository@maastrichtuniversity.nl

providing details and we will investigate your claim.
}

Copyright and moral rights for the publications made accessible in the public portal are retained by the authors and/or other copyright owners and it is a condition of accessing publications that users recognise and abide by the legal requirements associated with these

- Users may download and print one copy of any publication from the public portal for the purpose of private study or research.

- You may not further distribute the material or use it for any profit-making activity or commercial gain

If the publication is distributed under the terms of Article $25 \mathrm{fa}$ of the Dutch Copyright Act, indicated by the "Taverne" license above, 


\title{
Serotonin and Cognitive Flexibility: Neuroimaging Studies into the Effect of Acute Tryptophan Depletion in Healthy Volunteers
}

\author{
E.A.T. Evers ${ }^{*, a}$, F.M. van der Veen ${ }^{\mathrm{b}}$, D. Fekkes ${ }^{\mathrm{b}, \mathrm{c}}$ and J Jolles ${ }^{\mathrm{a}}$ \\ ${ }^{a}$ Department of Psychiatry and Neuropsychology, Brain and Behavior Institute, Maastricht University, Maastricht, Netherlands \\ ${ }^{b}$ Department of Psychiatry, Erasmus Medical Centre, Rotterdam, Netherlands \\ ${ }^{c}$ Department of Neuroscience, Laboratory of Neurobiology, Erasmus Medical Centre, Rotterdam, Netherlands
}

\begin{abstract}
Cognitive flexibility is the ability to adjust behavior to changes in the environment or task conditions. Previous research suggested that serotonin (5-HT) is involved in cognitive flexibility. Disturbed 5-HT functioning in animals, psychiatric patients and healthy volunteers leads to more rigid behavior. A well recognized method to manipulate levels of brain 5-HT is acute tryptophan depletion (ATD). This method induces a transient and reversible lowering of plasma tryptophan that has been shown to result in decreased brain 5HT. Only recently has ATD research been combined with functional Magnetic Resonance Imaging (fMRI). In this review, we discuss recent investigations into the effect of ATD on the Blood Oxygen Level Dependent (BOLD) response during tasks that require cognitive flexibility, in healthy volunteers.

Functional MRI studies have shown that ATD changes brain activation during tasks that require cognitive flexibility. It is hypothesized that ATD changes the processing of negative feedback, rather than impairing response inhibition, impairing the response to an error or the loss of cognitive control during response interference. Although the results of these studies are intriguing, they are sometimes contradictory. This could be the result of the different paradigms that have been used. Importantly, these studies strongly suggest that future multidisciplinary research should evaluate the mechanisms underlying individual differences and control for variables that have been shown to interact with the effect of ATD on cognitive flexibility and the related brain activation.
\end{abstract}

Keywords: Serotonin, acute tryptophan depletion, cognitive flexibility, functional neuroimaging.

Cognitive flexibility refers to the ability to switch between behavioral strategies, when changes in the environment lead to alterations in the outcome of actions. Previous research suggests that serotonin (5-HT) is involved in cognitive flexibility. Animal research showed that low 5-HT leads to inflexible behavior during reversal learning and response inhibition [1-4]. Furthermore, psychiatric disorders that show abnormal 5-HT functioning, such as major depression and obsessive compulsive disorder (OCD), are associated with rigid behavior [5-7]. Acute tryptophan depletion (ATD) is a well-established method to temporarily lower central 5HT. Some studies have shown that ATD impairs cognitive flexibility in healthy volunteers [8-11].

Although previous research suggests that 5-HT is important for cognitive flexibility, it is largely unknown how disturbed 5-HT levels change brain activation during tasks that require flexible behavior. Neuroimaging techniques such as functional Magnetic Resonance Imaging (fMRI) and positron emission tomography (PET) are used to investigate which brain areas are activated during task performance. These techniques will enable us to gain more insight into the effect of disturbed 5-HT functioning on brain activation associated with task performance. Thus far only a small number of studies have investigated the effect of ATD on brain activation during tasks that require cognitive flexibility. Based on these studies we will hypothesize that ATD impairs cognitive flexibility by affecting negative feedback processing.

This review is an overview of multidisciplinary en multidimensional research: a combination of chemistry, neurobiology and cognitive neuroscience. A review that discusses these different aspects and focuses on the neuropsychological aspects is relevant for the understanding of this emerging field of research.

\section{ACUTE TRYPTOPHAN DEPLETION}

In this section we will discuss the method of ATD and its effect on the 5-HT system. The neurotransmitter 5-HT cannot cross the

*Address correspondence to this author at the Department of Psychiatry and Neuropsychology (DRT 10), Maastricht University, P.O. Box 616, 6200 MD Maastricht, the Netherlands; Tel: +31-(0)43-3884086; Fax: +31-(0)43-3884092;

E-mail: 1.evers@np.unimaas.n blood-brain barrier (BBB) and therefore, its synthesis in the central nervous system (CNS) is dependent on its precursors, i.e. tryptophan (TRP) and 5-hydroxytryptophan (5-HTP). The amino acid TRP is hydroxylated to 5-HTP by the enzyme TRP hydroxylase (EC 1.13.99.3). This enzyme has a low affinity for TRP and is under normal physiological conditions not saturated with TRP, and thus its activity is dependent on the (central) availability of this amino acid [12]. An effective way to lower central 5-HT synthesis is by using a dietary amino acid load which does not include TRP, but does include a mixture of amino acids, which compete with TRP for the BBB [13]. This method is called ATD and has been used as a model for depression in order to gain more insight into the etiology and symptoms of depression [14-16].

Acute dietary depletion of TRP markedly reduces brain 5-HT content and this effect is accomplished by a dramatic decrease of the flux of TRP from blood to brain, which is caused by virtue of the property of the carrier protein that transports only large neutral amino acids (LNAA) across the BBB. This protein binds and actively transports the following LNAA: TRP, tyrosine, phenylalanine, valine, leucine and isoleucine, which compete with each other for BBB transport [13]. The rate of passage of TRP across the $\mathrm{BBB}$ is therefore dependent on the relative peripheral availability of TRP versus the other LNAA, expressed as the TRP/LNAA ratio [17]. When a TRP-free amino acid drink of 15 amino acids is given to healthy male volunteers, reductions of plasma free and total TRP levels of $45-91 \%$, depending on the dosage, were caused within 5-7 $\mathrm{h}$ after ingestion of this mixture $[18,19]$. The change in total as well as free TRP/LNAA ratio was even higher [20]. The primary mechanism for depleting brain TRP after a load of this amino acid drink is the increase in protein synthesis by the liver resulting in a decrease of peripheral TRP stores. This has been substantiated by experiments with rats, which showed that ATD reduced serum and brain TRP levels and levels of the 5-HT metabolite 5hydroxyindoleacetic acid (5-HIAA) [21]. Other animal experiments have confirmed that ATD also reduces synthesis and release of 5HT in the CNS [22]. Experiments that compared ATD with depletion with the amino acid lysine showed that ATD is specific for 5HT metabolism in CNS and that this procedure did not affect brain protein synthesis in general [23]. In humans, one of the first studies providing evidence for a decline in the rate of 5-HT induced by 
ATD in the brain was by PET using specific radiolabelled precursors [24].

Other studies investigated the effect of ATD on the 5-HT transporter and 5-HT receptors. Two human PET studies showed that ATD did not affect the binding potential of the 5-HT transporter $[25,26]$ and the $5-\mathrm{HT}_{1 \mathrm{~A}}$ receptor [27]. A PET study by Yatham et al. [28] showed that ATD decreased the binding potential of the 5$\mathrm{HT}_{2}$ receptor in various cortical regions. These studies suggest that ATD might decrease cortical 5- $\mathrm{HT}_{2}$ receptor density in humans. A rat study by Cahir et al. [29], however, showed that ATD did not affect $5-\mathrm{HT}_{2 \mathrm{~A}}$ binding (cortex and striatum). Furthermore, they showed that ATD reduced 5- $\mathrm{HT}_{1 \mathrm{~A}}$ binding in the dorsal raphe, but did not change the post synaptic $5-\mathrm{HT}_{1 \mathrm{~A}}$ binding. Interestingly, Lieben et al. [30] showed that the 5- $\mathrm{HT}_{6}$ antagonist Ro4368554 reversed memory deficits induced by ATD in rats. Obviously, these effects of ATD need to be replicated and more research is needed to examine the effect of ATD on the 5-HT system.

\section{OPERATIONAL PARADIGMS OF COGNITIVE FLEXI- BILITY}

Different operational paradigms have been used to study cognitive flexibility. Typically, these tasks require the subjects to choose an appropriate response, and adjust the response strategy based on feedback. Task that have been used to measure cognitive flexibility are reversal learning, decision making, gambling and the intradimensional/extra dimensional (ID/ED) shift task.

In cognitive flexibility a number of cognitive subprocesses are involved. A disturbance in one of these subprocesses is likely to impair cognitive flexibility. Cognitive subprocesses involved are among others response inhibition (hold back a response to the previously rewarded stimuli), the ability to overcome response interference (ignore competing response tendencies) and feedback processing (reward or punishment signals). In the studies discussed in this review response inhibition was studied by a Go/NoGo or a Stop
Signal task and response interference by a Stroop task. Feedback processing was studied by tasks in which feedback is given, such as a decision making or a reversal learning task (see Fig. 1). Another task that measures aspects of cognitive flexibility is the verbal fluency task. This executive task involves the use of cognitive strategies, inhibition of already mentioned words and the ability to shift to a new category.

\section{EFFECTS OF ATD ON FLEXIBLE BEHAVIOR}

A number of human studies have reported that ATD impairs cognitive flexibility $[8-11,31]$. These results are supported by two animal studies that showed impaired cognitive flexibility after prefrontal 5-HT depletion $[32,33]$. In contrast, other studies did not find effects of ATD on cognitive flexibility [34, 35]. Talbot et al. [35] showed that ATD improved decision making but did not affect reversal learning. Talbot et al. [35] hypothesized that personality characteristics play a decisive role in the effect of ATD on cognitive performance. Support for this hypothesis is provided for example by Cools et al. [36, 37]. These researchers showed that ATD modulated the amygdala activation in response to fearful faces as a function of self-reported threat sensitivity [37], and impaired motivational guidance of goal-directed behavior as a function of the trait impulsivity [36]. Furthermore, neuroimaging studies failed to find effects of ATD on performance measures of cognitive flexibility (see Table 1). The absence of performance changes might be related to the adaptations that are needed to make a behavioral task suitable for fMRI, such as an increased number of trials.

Cognitive inflexibility may be the result of an impairment of one of the subprocesses that underlie cognitive flexibility. Behavioral studies showed that ATD does not affect response inhibition in healthy volunteers without a genetic vulnerability that is known to interact with ATD, such as a family history of depression or alcoholism [38-41]. Although ATD does not seem to affect response inhibition, Walderhaug et al. [42] showed that ATD increased an

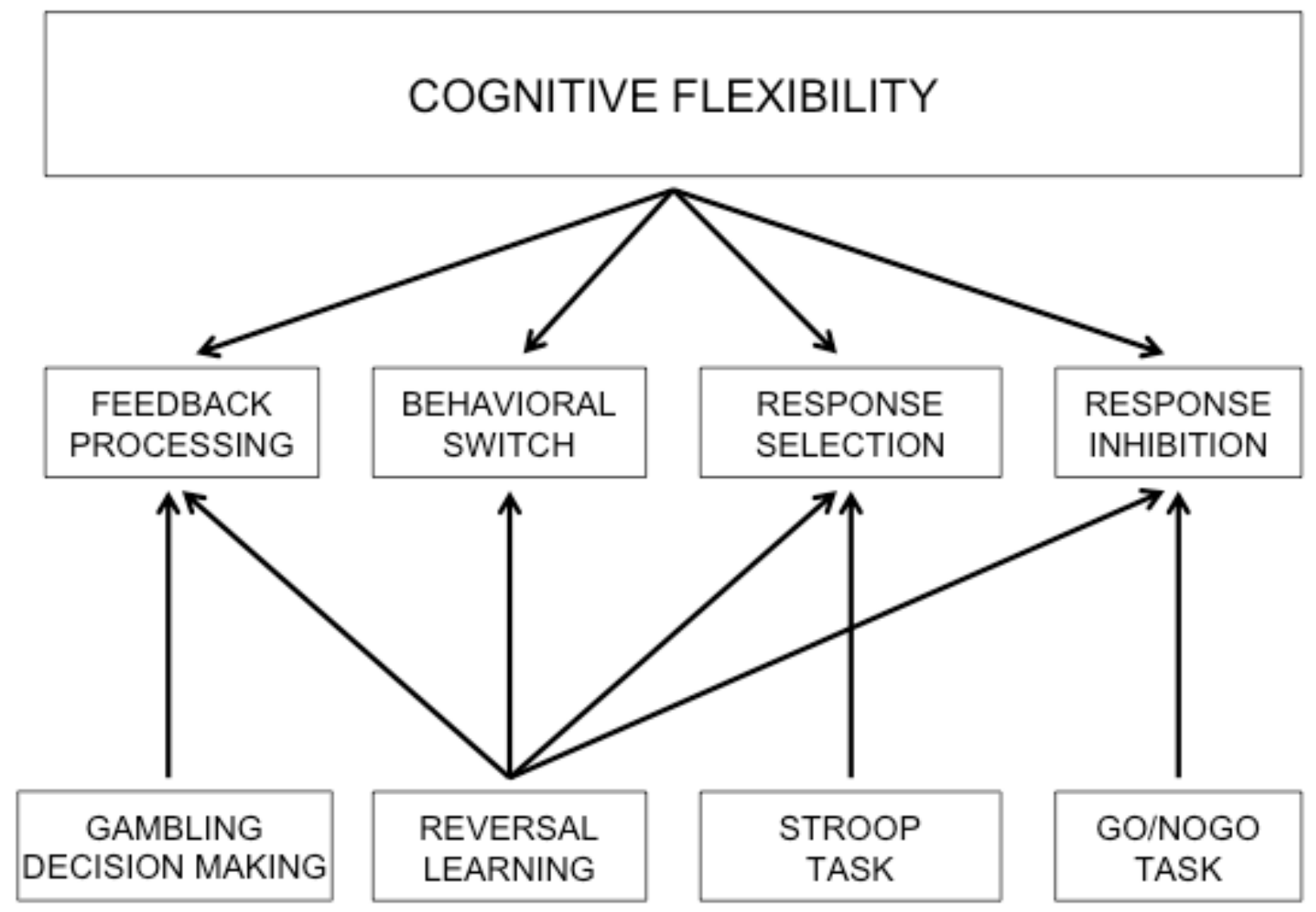

Fig. (1). The cognitive subprocesses that are involved in cognitive flexibility and paradigms that have been used to asses these cognitive processes. 
Table 1. The Studies that Investigated the Effect of ATD on Brain Activation During Tasks that Measure Cognitive Flexibility or Subprocesses that Underlie Cognitive Flexibility

\begin{tabular}{|c|c|c|c|c|c|c|}
\hline $\begin{array}{c}\text { Study } \\
\text { [reference number] }\end{array}$ & $\begin{array}{l}\text { Research } \\
\text { technique }\end{array}$ & Cognitive task & Participants & $\begin{array}{l}\text { Effect of ATD } \\
\text { on behavior }\end{array}$ & $\begin{array}{c}\text { Effect of ATD } \\
\text { on the BOLD response }\end{array}$ & $\begin{array}{l}\text { Cognitive process } \\
\text { under investigation }\end{array}$ \\
\hline Evers et al. 2005 [59] & Functional MRI & Reversal learning task & $\begin{array}{l}\text { Healthy volunteers } \\
\quad(11 \text { males })\end{array}$ & No effect & $\begin{array}{l}\text { ATD increased the response in } \\
\text { the dorsomedial PFC (BA 8) }\end{array}$ & Reversal learning \\
\hline Rubia et al. 2005 [60] & Functional MRI & Go/NoGo task & $\begin{array}{l}\text { Healthy volunteers } \\
\text { ( } \mathrm{n}=9 \text {, males and } \\
\text { females) }\end{array}$ & No effect & $\begin{array}{l}\text { ATD decreased the response in } \\
\text { the right inferior/orbitofrontal } \\
\text { PFC (BA 47, BA 45/6) and in- } \\
\text { creased the response in the supe- } \\
\text { rior and medial temporal cortices } \\
\text { (BA 21/37). }\end{array}$ & Response inhibition \\
\hline Evers et al. 2006 [61] & Functional MRI & Go/NoGo task & $\begin{array}{l}\text { Healthy volunteers } \\
\quad(13 \text { males })\end{array}$ & No effect & $\begin{array}{l}\text { ATD decreased the response in } \\
\text { the dorsomedial PFC (BA 8). } \\
\text { ATD did not change the response } \\
\text { during response inhibition. }\end{array}$ & $\begin{array}{c}\text { Performance monitor- } \\
\text { ing } \\
\text { Response inhibition }\end{array}$ \\
\hline $\begin{array}{c}\text { Horacek et al. } 2005 \\
{[62]}\end{array}$ & Functional MRI & Stroop task & $\begin{array}{l}\text { Healthy volunteers } \\
\text { (10 males, } 10 \\
\text { females) }\end{array}$ & No effect & $\begin{array}{l}\text { ATD increased the response in } \\
\text { the left inferior frontal (BA 47) } \\
\text { and the right medial frontal cortex } \\
\text { (BA 10). }\end{array}$ & Response interference \\
\hline Evers et al. 2006 [43] & Functional MRI & Stroop task & $\begin{array}{l}\text { Healthy volunteers } \\
\text { (15 females) }\end{array}$ & $\begin{array}{l}\text { ATD decreased } \\
\text { the interference } \\
\text { score }\end{array}$ & $\begin{array}{l}\text { ATD increased ACC (BA 32) } \\
\text { activation in the } 1^{\text {st }} \text { Stroop block } \\
\text { the participants performed. }\end{array}$ & Response interference \\
\hline Allen et al. 2006 [64] & Functional MRI & Verbal fluency task & $\begin{array}{l}\text { Healthy volunteers } \\
\text { ( } 8 \text { males, } 2 \text { females) }\end{array}$ & No effect & $\begin{array}{l}\text { ATD decreased the response in } \\
\text { the precuneus (BA 7) and the } \\
\text { medial frontal gyrus (BA 6) }\end{array}$ & Cognitive flexibility \\
\hline $\begin{array}{c}\text { Morris et al. } 1999 \\
{[51]}\end{array}$ & PET & Verbal fluency task & $\begin{array}{c}\text { Remitted depressed } \\
\text { patients ( } 8 \text { males) }\end{array}$ & No effect & $\begin{array}{l}\text { ATD reduced the response in the } \\
\text { left ACC and the amygdala }\end{array}$ & $\begin{array}{l}\text { Verbal fluency rela- } \\
\text { tive to word repetition }\end{array}$ \\
\hline Smith et al. 1999 [52] & PET & Verbal fluency task & $\begin{array}{c}\text { Remitted depressed } \\
\text { patients ( } 8 \text { males) }\end{array}$ & No effect & $\begin{array}{l}\text { The dorsal ACC showed modula- } \\
\text { tion of its activation by depressed } \\
\text { mood. }\end{array}$ & Verbal fluency \\
\hline
\end{tabular}

$\mathrm{ACC}=$ Anterior Cingulate Cortex; ATD = Acute Tryptophan Depletion; BA = Brodmann Area; BOLD = Blood Oxygen Dependent Response; MRI = Magnetic Resonance Imaging; $\mathrm{PET}=$ Positron Emission Tomography.

impulsive response style on a continuous performance test. In contrast with the human data is a rat study that showed that the reversal deficit induced by prefrontal 5-HT depletion was due specifically to a failure to inhibit responding to the previously rewarded stimulus [33]. Previous studies showed that ATD did not impair but improved focused attention during response interference [43, 44]. ATD impaired the processing of reward information. Rogers et al. [11] reported that ATD reduced discrimination between magnitudes of expected gain in a gambling paradigm. Cools et al. [37] found reduced reward-related speeding of response times in a cuedreinforcement reaction time task. Interestingly, Roiser et al. [45] showed that this reduction was restricted to the volunteers homozygous for the short allele (ss) of the 5-HTTLPR. Finger et al. [46] showed that ATD impaired the response to reward on a passive avoidance task. Additionally, this study showed that the effect of ATD on the processing of punishment information interacted with the 5-HTTLPR allele polymorphism: tryptophan depleted individuals homozygous for the long allele (11) failed to appropriately use punishment information, but not the individuals homozygous for the short allele (ss).

Although, some of the mentioned studies show that ATD impairs cognitive flexibility and subprocesses important for cognitive flexibility, effects are often weak and inconsistent. The effect of ATD on cognitive flexibility as well as the influence of individual differences needs to be further established.

\section{THE EFFECT OF ATD ON BRAIN ACTIVATION DUR- ING COGNITIVE FLEXIBILITY}

The above discussed behavioral studies are limited to making inferences about the psychological processes that are affected by ATD. The underlying brain mechanisms can be studied by using various neuroimaging techniques such as PET and fMRI. In a PET scan a radioactive tracer like ${ }^{15} \mathrm{O}$ or ${ }^{18} \mathrm{~F}$ is built into a molecule like $\mathrm{H}_{2} \mathrm{O}$ and injected into the human body. By monitoring the positron emission decay of the tracer with a large amount of detectors the exact location of tracer can be determined. In this way it is possible to determine the spatial distribution of the tracer in the body, and makes it possible to estimate processes like blood flow or glucose consumption in specific areas of the brain (for review see [47, 48]). The early studies which combined PET with ATD mostly focused on psychiatric populations and measurements of the resting brain [49-52]. These studies showed that ATD especially influenced activation in the anterior cingulate cortex (ACC) and orbitofrontal cortex. These changes strongly depend on individual mental health status, such as vulnerability to depression [53-58].

Clear disadvantages of the PET technique are the invasive nature and the relatively poor temporal resolution. Therefore, more recent studies have used fMRI which is not invasive and offers better temporal resolution. The fMRI technique is based on the different magnetic properties of oxygenated and deoxygenated hemoglobin molecules, which lead to slightly different magnetic resonance signal in blood carrying more or less oxygenated hemoglobin. The general idea is that more active neural tissue leads to more blood flow to this tissue and to a higher percentage of oxygenated hemoglobin molecules, leading to a change in the so-called BloodOxygen Level Dependent (BOLD) response. So, this BOLD response can be used to distinguish more active neural tissue from less active tissue.

The digital archive Pubmed (http://www.ncbi.nlm.nih.gov/sites/ entrez?db=pubmed) and the keywords 'tryptophan depletion', and 'fMRI' or 'PET' were used to find studies that investigated the effect of ATD on brain activation during cognitive flexibility. In 
total, six fMRI en two PET studies were found (see Table 1). In these studies either healthy volunteers or remitted depressed patients were tested using a counterbalanced placebo-controlled within-subject design. No studies were found that examined the effect of ATD on brain activation during cognitive flexibility in depressed patients or other patient groups.

\section{Reversal Learning}

Evers et al. [59] investigated the effect of ATD on probabilistic reversal learning in healthy volunteers. In this two choice discrimination task two abstract patterns were presented. Based on feedback, participants had to find out which of the two patterns was the most advantageous. During the task the stimulus-reward contingency was reversed several times. The task was designed in such a way that brain activation related to 1) correct responses, 2) reversal switch errors (errors due to a reversal in reinforcement contingency after which the subject switched response) and 3) other errors, could be separated. ATD did not change performance. ATD increased activation in the dorsomedial prefrontal cortex (dmPFC) when reversal switch errors (negative feedback followed by a behavioral switch) were contrasted with correct responses, and tended to increase this activation when other errors (negative feedback without behavioral switch) were contrasted to correct trials. No significant effect of ATD was found when reversal switch errors were contrasted with other errors. These results suggest that ATD affects reversal learning by changing the processing of negative feedback by modulation of the dmPFC.

\section{Response Inhibition}

Two fMRI studies $[60,61]$ investigated the effect of ATD on response inhibition during a $\mathrm{Go} / \mathrm{NoGo}$ task in healthy volunteers. In the study by Rubia et al. [60] participants performed a choice reaction time task, in which they had to press a button when they saw an arrow pointing left or right, and to withhold their response when the arrow pointed upwards. Although ATD did not affect performance, it decreased right inferior/orbitofrontal PFC activation and increased activation in the superior and medial temporal cortices during response inhibition. The authors concluded that these results provide evidence for a serotonergic modulation of the right inferior frontal cortex during response inhibition. In the study by Evers et al. [61] participants performed a Go/NoGo task in which a stream of letters was presented. The participants had to respond when the saw a Y preceded by an X, or an X preceded by a Y. When an X or $Y$ was repeated, they had to withhold their response. Feedback was given after each response. The effect of ATD on performance monitoring (a response error followed by negative feedback) and response inhibition was studied. ATD did not affect the reaction time on a trial after an error, but decreased the BOLD response in the dorsomedial PFC after an error. ATD did not affect response inhibition performance and the related brain activation. These two studies show different effects of ATD on brain activation during response inhibition. These differences might be due to task and design related differences, such as difficulty, feedback and gender of the participants.

\section{Response Interference}

Two fMRI studies investigated the effect of ATD on response interference during a Stroop task in healthy volunteers. Horacek et al. [62] tested performance during a Stroop task that consisted of a color naming, a word reading and an interference subtest. In addition, these participants were tested in the MRI scanner during a Stroop task that included blocks in which color congruent and blocks in which color incongruent words (e.g. "red" written in green ink) were presented. No effects of ATD were found on Stroop performance. ATD increased the BOLD response in the left inferior frontal cortex and the right medial frontal cortex during response interference. Evers et al. [43] tested the effect of ATD on response interference during a combined emotional and cognitive Stroop task. Participants performed two Stroop blocks in the MRI scanner in which congruent color, incongruent color and emotional words were semi randomly presented. They had to report the color of the ink by pressing one out of four response buttons. ATD decreased the interference score, which is an index for the reaction time on incongruent color relative to congruent color words. ATD increased the ACC activation when incongruent color words were compared to congruent color words in the first Stroop block. Furthermore, ATD increased the BOLD response in the left precuneus and cuneus during congruent color words. These two studies showed that ATD does not impair performance by increasing response interference. The differences in the effect of ATD on brain activation in these two studies could be related to methodological problems associated with the Horacek study: in the scanner, the participants only had to watch the colored words and did not have to indicate the color of these words with a response.

Of interest is a study by Morgan et al. [63] that investigated the effect of TRP administration during a counting Stroop task in healthy volunteers. This task consisted of neutral (names of animals) and interference (names of numbers) blocks. Subjects were instructed to report the number of words. Interference was caused by a difference in the meaning of the words and the number of words presented (e.g. "two" was presented three times). TRP administration did not affect performance. TRP administration decreased the activation in the post central, the inferior frontal and the angular cortex, and increased the activation in the precuneus and the posterior cingulate gyrus during response interference.

\section{Verbal Fluency}

In an fMRI study, Allen et al. [64] investigated the effect of ATD on two tasks that are known to engage PFC activation, namely a 2-back verbal working memory and a phonological verbal fluency task, in healthy volunteers. In both tasks, performance was unchanged after ATD. In the n-back task, ATD decreased the activation in the superior frontal gyrus and increased the activation in the posterior cingulate gyrus. In the verbal fluency task, ATD decreased the activation in the precuneus and the medial frontal gyrus. In addition, two PET studies investigated the effect of ATD during verbal fluency in remitted depressed patients. Morris et al. [51] tested remitted patients during a paced word repetition and an orthographic verbal fluency task. ATD did not affect performance. Activity in the dorsal raphe nucleus and the habenula covaried positively, while activation in the septal region, amygdala and the orbitofrontal cortex covaried negatively with plasma TRP levels. ATD reduced the activation in the left ACC and the amygdala in the verbal fluency relative to the word repetition task. Smith et al. [52] used the same data set, but focused on the correlation between induced depressed mood and brain activation. The dorsal ACC showed modulation of its activation by depressed mood when participants performed a verbal fluency task, but not when they performed the repetition task. When the participants were more depressed after ATD, less activation was seen in the dorsal ACC. These studies showed that mood can be a confounder when the effect of ATD on cognition is studied. However, in the majority of studies, ATD did not induce depressed mood in healthy volunteers $[19,65]$, although small effects on mood have been reported [19, 65-67], possibly related to a vulnerability for depression [49, 5358].

\section{DISCUSSION}

\section{The Effect of ATD on Cognitive Flexibility}

In the former section we have discussed the results of neuroimaging studies that investigated the effect of a transient lowering of 
5-HT on cognitive flexibility and on cognitive subprocesses that are important for cognitive flexibility. Evers et al. [59] showed that ATD increased the activation in the dmPFC during reversal learning. Previous studies reported that depressed patients showed a catastrophic response to failure [68] or oversensitivity to negative feedback $[69,70]$. Based on these studies and our own results, we hypothesized that ATD affects cognitive flexibility via negative feedback processing.

However, this study does not exclude the possibility that ATD affects response inhibition, performance monitoring or response conflict during reversal learning. Excluding these possibilities would provide indirect evidence for our hypothesis. The results of the two studies that investigated the effect of ATD on response inhibition were inconclusive $[60,61]$. Because the majority of behavioral studies did not show effects of ATD on response inhibition [37-41], ATD seems unlikely to impair cognitive flexibility by impairing response inhibition. The effect of ATD on performance monitoring (error followed by negative feedback) was examined in Evers et al. [61]. This study showed that ATD changed brain activation during performance monitoring. Since EEG studies did not find an effect of ATD (Evers et al. unpublished data) or the first line antidepressant mirtazipine [71] on the error-related negativity (an error component that is seen before feedback is received), this might suggest that the effect of ATD on performance monitoring is caused by an effect on the processing of negative feedback. Horacek et al. [62] and Evers et al. [43] investigated the effect of ATD on response interference during a Stroop task. Based on the results of behavioral studies, that showed that ATD improved or did not affect Stroop interference [34, 62, 72-75], and the methodological problems with the Horacek et al. [62] study, we suggest that ATD is unlikely to impair reversal learning by an increase in response interference.

To conclude, these studies might suggest that ATD affects cognitive flexibility by changing the processing of negative feedback, rather than by impairing response inhibition, the response to an error or an increase in response conflict. However, this hypothesis is still premature and strong evidence is up till now lacking. Furthermore, since genetic makeup seems important for the effect of ATD on the processing of negative information [46], future studies should unravel the association between the effect of ATD on negative feedback modulated by the dorsomedial PFC and the types of alleles for the 5-HTTLPR.

Previous research showed that ATD affects the processing of reward information: participants are less motivated by properties of stimuli predictive of reward [37,45], make more failures to respond to a rewarded stimulus [46] and show reduced discrimination between different magnitudes of reward [11]. The effects of ATD on reversal learning [59] might have been affected by an effect of ATD on reward. Firstly, reward plays a general role in cognitive flexibility: behavior is adjusted in order to regain positive feedback or reward. Secondly, in the effect of ATD on dmPFC activation during reversal learning [59] reward was involved: reversal switch errors (followed by negative feedback) were compared with correct response (followed by positive feedback). When considering the effects of ATD on rewards during cognitive flexibility it is important to note the majority of studies so far have related reward with the dopaminergic system [76-78].

\section{Interactions of Low 5-HT with other Neurotransmitters}

ATD might interact with other neurotransmitter systems. It has been shown that 5-HT acts through several 5-HT receptor and modulates not only the release of acetylcholine, noradrenalin, glutamate and GABA [79], but also that of dopamine in all three major dopaminergic pathways [for review see 80 ]. It has been suggested that the improvement of focused attention during Stroop performance after ATD might be the result of increased DA [43]. However, effects of ATD on the DA system have not been found so far [81]. Booij et al. [82] reported that ATD did not affect the plasma DA metabolite homovanillic acid (HVA), while 5-HIAA levels were significantly reduced. Young et al. [83] showed that tyrosine and the catecholamine metabolites were unchanged after ATD in primates. Carpenter et al. [84] showed that despite a rise in tyrosine, no change in the amount of the major DA metabolite HVA was found after ATD in human cerebrospinal fluid (CSF). Lieben et al. [85] examined the effects of ATD with a gelatin collagen protein (CP) mixture on the levels of 5-HT, 5-HIAA, DA and the DA metabolite DOPAC (3,4-dihydroxyphenylacatic acid) in the rat brain. They showed that after ATD the levels of 5-HT and 5-HIAA were significantly reduced in the striatum, the hippocampus and the cortex, whereas levels of DA and DOPAC were unchanged in these areas. Another system that might be affected by ATD is the opioid system, since ATD was found to abolish the analgesic effect of morphine in human volunteers [86].

\section{The Dissociation Between the Effect of ATD on Brain Activa- tion and Performance}

In most of the neuroimaging studies discussed in this review article, ATD resulted in changed brain activation without affecting performance (see Table 1). We will discuss five possible explanations for this dissociation.

Firstly, there is no effect of ATD on cognitive flexibility and the differential brain activation seen during ATD has no significant association with the performed task. This explanation is based on the inconsistent effects of ATD on cognitive flexibility. The discussed results, however, show that effects of ATD on brain activation are only seen during specific cognitive events, such as after making a reversal error. Therefore this explanation is unlikely to be correct.

Secondly, the effect of ATD on performance might be hidden because of learning effects. In the reviewed studies cognitive tasks are often well practiced: the participants performed the task during a practice, a depleted and a balanced session. Previous research showed that ATD impairs performance on a reversal learning task when the task was novel to the subjects $[8,9]$.

Thirdly, the cognitive tasks used measure a combination of cognitive subprocesses, while previous studies suggest that not all of these processes are changed by ATD. For example, during a reversal switch in a reversal learning task the following subprocesses are involved: feedback processing, learning new stimulusreward associations, inhibition of the response related to the previous stimulus-reward associations and behavioral adaptation. Because negative feedback processing is only one of the processes involved in reversal learning it is possible that changes in negative feedback processing do not show in the behavioral outcome measures.

Fourthly, it is possible that ATD influences the cognitive strategy the participants used to successfully perform the tasks. Participants might need to recruit more or less effort, or might need to recruit other brain structures to reach the same level of performance. As a result brain activation patterns change, but performance is comparable. For example, Dibbets et al. [87] showed that children with specific language impairment recruit other brain regions than children without this impairment during a task switching paradigm, while performance is comparable between these two groups.

Fifth and finally, neuroimaging might capture aspects of cognition that performance measures can not. Neuroimaging studies show brain activation patterns that underlie cognitive processes, while performance measures show the behavioral outcome of these brain mechanisms. Performance measures like reaction times and accuracy might therefore be imperfect measures of cognition. Our results might add to the suggestion that the BOLD response is more 
sensitive to detect changes in cognition than performance measures [88].

Importantly, the second until fourth explanation support the fifth explanation. If the second explanation is correct, neuroimaging is able to show effects of ATD on reversal learning, while learning effects prevented effects of ATD on performance. If the third explanation is correct, neuroimaging is able to show effects of ATD on performance monitoring in a reversal learning and $\mathrm{Go} / \mathrm{NoGo}$ task while performance measures were not able to dissociate between the effects of ATD on different cognitive subprocesses. If the fourth explanation is correct, neuroimaging is able to show that ATD leads to brain activation changes due to changes in effort or cognitive strategy, while performance outcomes are unchanged.

It remains to be tested by future research which explanation is correct. Importantly, all explanations, except the first, show the importance of neuroimaging methods for cognitive research.

\section{The Influence of Biological and Psychological Factors}

Previous studies showed that the effects of ATD on cognition and the related brain activation are influenced by psychological and biological factors. ATD modulated the amygdala activation in response to fearful faces as a function of self-reported threat sensitivity [36] and impaired motivational guidance of goal-directed behavior on a cued-reinforcement task as a function of the trait impulsivity [37]. Previous research showed interactions between the 5HTTLPR genotype and the effect of ATD on motivational behavior and passive avoidance $[45,46]$. In addition, our own group confirmed the influence of biological factors on the effect of ATD [89]. The effect of ATD on facial recognition was studied in healthy women with and without a family history of depression. This study showed that the mood response ATD induced in women with a family history of depression, leads to more interference from negative faces and a stronger amygdala response. These studies indicate the importance of individual difference in ATD research and suggest that is it important for future research to control for biological and psychological factors that have shown to influence the effect of ATD.

This suggestion is supported by ATD studies that showed contradictory findings. For example, Rogers et al. [90] investigated the effect of ATD on a decision gambling task and showed that ATD decreased the tendency to choose the more likely outcome. Directly opposite are the results of Talbot et al. [35] who used the exact same task but showed that ATD increased the tendency to choose the more likely outcome. Based on the very similar designs of these studies and almost identical demographic characteristics of the participants, Talbot et al. [35] suggest that the different results are related to intrinsic trait characteristics of the participants. They therefore conclude that the contrast between these studies suggests the need for future ATD studies to control for personality, family history and genetic factors.

\section{CONCLUSION}

In conclusion, it can be said that the use of fMRI to determine the underlying brain mechanisms involved in the effect of acutely lowering serotonin levels by means of ATD have yielded intriguing and sometimes puzzling results. The studies performed so far have suggested that 5-HT plays a role in cognitive flexibility, but important modulating factors such as personality characteristics, genetic vulnerability factors and gender should be carefully controlled before strong conclusions can be drawn. The studies reviewed here provided strong arguments for the execution of experiments in which sources of individual variability are taken into consideration and even are the primary research question. Future studies should especially be devoted to differential vulnerability factors. Individual differences in genes that are involved in the 5-HT metabolism such as 5-HT transporter, tryptophan hydroxylase-2 and the different 5HT receptor genes should be taken into account to explain the complicated relation between 5-HT challenge tests such as ATD and cognitive functions such as cognitive flexibility. A further step could be to specifically look at gene expression and relate this to vulnerability to changes in 5-HT availability. As was stated before, the 5-HT system strongly interacts with other neurotransmitter systems, of which the DA system is possibly one of the most interesting from the perspective of psychiatric disorders. Therefore, future studies should also include genes which are involved in DA metabolism such as the catechol-O-methyl transferase (COMT) gene and genes that are more generally involved in monoamine metabolism, such as the monoamine oxidase A gene. Both mentioned genes have also been extensively linked to cognitive function and psychiatric disease. In our view a multidisciplinary approach in which multiple genes and other individual risk factors are taken into account would be most fruitful in making progression in this complicated area of research.

\section{ABBREVIATIONS}

\begin{tabular}{|c|c|c|}
\hline $\mathrm{ACC}$ & $=$ & Anterior Cingulate Cortex \\
\hline ATD & $=$ & Acute Tryptophan Depletion \\
\hline BA & $=$ & Brodmann Area \\
\hline BBB & $=$ & Blood-Brain Barrier \\
\hline BOLD & $=$ & Blood-Oxygen Level Dependent \\
\hline $\mathrm{CSF}$ & $=$ & Cerebrospinal Fluid \\
\hline $\mathrm{CNS}$ & $=$ & Central Nervous System \\
\hline COMT & $=$ & Catechol-O-Methyl Transferase \\
\hline $\mathrm{CP}$ & $=$ & Collagen Protein \\
\hline DA & $=$ & Dopamine \\
\hline DOPAC & $=$ & 3,4-Dihydroxyphenylacatic Acid \\
\hline fMRI & $=$ & Functional Magnetic Resonance Imaging \\
\hline HVA & $=$ & Homovanillic Acid \\
\hline OCD & $=$ & Obsessive-Compulsive Disorder \\
\hline ID/ED & $=$ & Intra-/Extra-Dimensional \\
\hline LNAA & $=$ & Large Neutral Amino Acids \\
\hline MRI & $=$ & Magnetic Resonance Imaging \\
\hline PET & $=$ & Positron Emission Tomography \\
\hline PFC & $=$ & Prefrontal Cortex \\
\hline TRP & $=$ & Tryptophan \\
\hline 5-HIAA & $=$ & 5-Hydroxyindoleacetic Acid \\
\hline 5-HT & $=$ & 5-Hydroxytryptamine, Serotonin \\
\hline 5-HTP & $=$ & 5-Hydroxytryptophan \\
\hline 5-HTTLPR & $=$ & $\begin{array}{l}\text { Serotonin Transporter (5-HTT) Gene-Linked Pro- } \\
\text { motor Region }\end{array}$ \\
\hline
\end{tabular}

\section{REFERENCES}

[1] Mazer, C.; Muneyyirci, J.; Taheny, K.; Raio, N.; Borella, A.; WhitakerAzmitia, P. Brain Res., 1997, 760, 68.

[2] Barnes, J.; Costall, B.; Coughlan, J.; Domeney, A.M.; Gerrard, P.A.; Kelly, M.E.; Naylor, R.J.; Onaivi, E.S.; Tomkins, D.M.; Tyers, M.B. Pharmacol. Biochem. Behav., 1990, 35, 955.

[3] Harrison, A.A.; Everitt, B.J.; Robbins, T.W. Psychopharmacology (Berl.), 1997, 133, 329.

[4] Harrison, A.A.; Everitt, B.J.; Robbins, T.W. Behav. Brain Res., 1999, 100, 99.

[5] Veale, D.; Sahakian, B.J.; Owen, A.M.; Marks, I.M. Psychol. Med., 1996, 26,1261 . 
[6] Houston, R.J.; Bauer, L.O.; Hesselbrock, V.M. Prog. Neuropsychopharmacol. Biol. Psychiatry, 2004, 28, 529.

[7] Fossati, P.; Ergis, A.M.; Allilaire, J.F. Encephale, 2002, 28, 97.

[8] Murphy, F.C.; Smith, K.A.; Cowen, P.J.; Robbins, T,W.; Sahakian, B.J. Psychopharmacology, 2002, 163, 42.

[9] Park, S.B.; Coull, J.T.; McShane, R,H.; Young, A.H.; Sahakian, B.J.; Robbins, T.W.; Cowen, P.J. Neuropharmacology, 1994, 33, 575.

[10] Rogers, R.D.; Blackshaw, A.J.; Middleton, H.C.; Matthews, K.; Hawtin, K.; Crowley, C.; Hopwood, A.; Wallace, C.; Deakin, J.F.; Sahakian, B.J.; Robbins, T.W. Psychopharmacology, 1999, 146, 482.

[11] Rogers, R.; Tunbridge, E.M.; Bhagwagar, Z.; Drevets, W.C.; Sahakian, B.J.; Carter, C.S. Neuropsychopharmacology, 2003, 28, 153.

[12] Wurtman, R.J.; Hefti, F.; Melamed, E. Pharmacol. Rev., 1980, 32, 315.

[13] Pardridge, W.M.; Oldendorf, W.H. Biochem. Biophys. Acta., 1975, 401, 128

[14] Delgado, P.L.; Charney, D.S.; Price, L.H.; Aghajanian, G.K.; Landis, H.; Heninger, G.R. Arch. Gen. Psychiatry, 1990, 47, 411.

[15] Moreno, F.A.; Gelenberg, A.J.; Heninger, G.R.; Potter, R.L.; McKnight, K.M.; Allen, J.; Phillips, A.P.; Delgado, P.L. Biol. Psychiatry, 1999, 46, 498.

[16] Neumeister, A. Psychopharmacol. Bull., 2003, 37, 99.

[17] Fernstrom, J.D.; Wurtman, R.J. Science, 1972, 178, 414

[18] Reilly, J.G.; McTavish, S.F.; Young, A.H. J. Psychopharmacol., 1997, 11, 381.

[19] Van der Does, A.J.W. Journal of Affective Disorders, 2001, 64, 107.

[20] Spillmann, M.K.; van der Does, A.J.; Rankin, M.A.; Vuolo, R.D.; Alpert, J.E.; Nierenberg, A.A.; Rosenbaum, J.F.; Hayden, D.; Schoenfeld, D.; Fava, M. Psychopharmacology (Berl.), 2001, 155, 123.

[21] Gessa, G.L.; Biggio, G.; Fadda, F.; Corsini, G.U.; Tagliamonte, A.J. Neurochem., 1974, 22, 869 .

[22] Gartside, S.E.; Cowen, P.J.; Sharp, T. Psychopharmacology (Berl.), 1992, $109,251$.

[23] Klaassen, T.; Riedel, W.J.; Deutz, N.E.; van Someren, A.; van Praag, H.M. Psychopharmacology (Berl.), 1999, 141, 279.

[24] Nishizawa, S.; Benkelfat, C.; Young, S.N.; Leyton, M.; Mzengeza, S.; de Montigny, C.; Blier. P.; Diksic, M. Proc. Nat. Acad. Sci., 1997, 94, 5308.

[25] Praschak-Rieder, N.; Wilson, A.A.; Hussey, D.; Carella, A.; Wei, C.; Ginovart, N.; Schwarz, M.J.; Zach, J.; Houle, S.; Meyer, J.H. Biol. Psychiatry, 2005, 558, 825 .

[26] Talbot, P.S.; Frankle, W.G.; Hwang, D.R.; Huang, Y.; Suckow, R.F.; Slifstein, M.; Abi-Dargham, A.; Laruelle, M. Synapse, 2005, 55, 164.

[27] De Haes, J.I.; Bosker, F.J.; Van Waarde, A.; Pruim, J.; Willemsen, A.T.; Vaalburg, W.; Den Boer, J.A. Synapse, 2002, 46, 108.

[28] Yatham, L.; Liddle, P.F.; Shiah, I.S.; Lam, R.W.; Adam, M.J.; Zis, A.P.; Ruth, T.J. British journal of psychiatry, 2001, 178, 448.

[29] Cahir, M.; Ardis, T.; Reynolds, G.P.; Cooper, S.J. Psychopharmacology (Berl.), 2006, 190, 497.

[30] Lieben, C.K.; Steinbusch, H.W.; Blokland, A. Behav. Brain Res., 2006, 168 , 197.

[31] Schmitt, J.A.; Wingen, M.; Ramaekers, J.G.; Evers, E.A.; Riedel, W.J. Curr. Pharm. Des., 2006, 12, 2473.

[32] Clarke, H.F.; Dalley, J.W.; Crofts, H.S.; Robbins, T.W.; Roberts, A.C. Science, 2004, 304, 878

[33] Clarke, H.F.; Walker, S.C.; Dalley, J.W.; Robbins, T.W.; Roberts, A.C. Cereb. Cortex, 2007, 17, 18.

[34] Gallagher, P.; Massey, A.E.; Young, A.H.; McAllister-Williams, R.H. BMC Psychiatry, 2003, 3, 10.

[35] Talbot, P.; Watson, D.R.; Barrett, S,L.; Cooper, S.J. Neuropsychopharmacology, 2006, 31, 1519.

[36] Cools, R.; Calder, A.J.; Lawrence, A.D.; Clark, L.; Bullmore, E.; Robbins, T.W. Psychopharmacology (Berl.), 2005, 180, 670.

[37] Cools, R.; Blackwell, A.; Clark, L.; Menzies, L.; Cox, S.; Robbins, T.W. Neuropsychopharmacology, 2005, 30, 1362.

[38] Clark, L.; Roiser, J.P.; Cools, R.; Rubinsztein, D.C.; Sahakian, B.J.; Robbins, T.W. Psychopharmacology (Berl.), 2005, 182, 570-8.

[39] LeMarquand, D.G.; Pihl, R.O.; Young, S.N.; Tremblay, R.E.; Seguin, J.R.; Palmour, R.M.; Benkelfat, C. Neuropsychopharmacology, 1998, 19, 333.

[40] LeMarquand, D.G.; Benkelfat, C.; Pihl, R.O.; Palmour, R.M.; Young, S.N. Am. J. Psychiatry, 1999, 156, 1771 .

[41] Crean, J.; Richards, J.B.; de Wit, H. Behav. Brain Res., 2002, 136, 349.

[42] Walderhaug, E.; Lunde, H.; Nordvik, J.E.; Landro, N.I.; Refsum, H.; Magnusson, A. Psychopharmacology (Berl.), 2002, 164, 385.

[43] Evers, E.A.; van der Veen, F.M.; Jolles, J.; Deutz, N.E.; Schmitt, J.A. Neuroimage, 2006, 32, 248.

[44] Schmitt, J.A.; Jorissen, B.L.; Sobzak, S.; van Boxtel, M.P.; Hogervorst, E.; Deutz, N.E.; Riedel, W.J. J. Psychopharmacol., 2000, 14, 21.

[45] Roiser, J.; Blackwell, A.D.; Cools, R.; Clark, L.; Rubinsztein, D.C.; Robbins, T.W.; Sahakian, B.J. Neuropsychopharmacology, 2006, 31, 2264.

[46] Finger, E.C.; Marsh, A.A.; Buzas, B.; Kamel, N.; Rhodes, R.; Vythilingham, M.; Pine, D.S.; Goldman, D.; Blair, J.R. Neuropsychopharmacology, 2007, $32,206$.

[47] Cherry, S.R.; Phelps, M.E. In Brain Mapping: The Methods, Toga, A.W.; Mazziotta, J.C., Ed.; Academic Press: San Diego, Calif., 2002; pp. 485-511.
[48] Reba, R.C. J. Clin. Psychiatry, 1993, 54, 26.

[49] Neumeister, A.; Nugent, A.C.; Waldeck, T.; Geraci, M.; Schwarz, M.; Bonne, O.; Bain, E.E.; Luckenbaugh, D.A.; Herscovitch, P.; Charney, D.S.; Drevets, W.C. Arch. Gen. Psychiatry, 2004, 61, 765.

[50] Bremner, J.D.; Innis, R.B.; Salomon, R.M.; Staib, L.H.; Ng, C.; Miller, H.L.; Bronen, R.A.; Krystal, J.H.; Duncan, J.; Rich, D.; Price, L.H.; Malison, R.; Dey, H.; Soufer, R.; Charney, D.S. Arch. Gen. Psychiatry, 1997, 54, 364.

[51] Morris, J.S.; Smith, K.A.; Cowen, P.J.; Friston, K.J.; Dolan, R.J. Neuroimage, 1999, 10, 163.

[52] Smith, K.A.; Morris, J.S.; Friston, K.J.; Cowen, P.J.; Dolan, R.J. British journal of psychiatry, 1999, 174, 525 .

[53] Ellenbogen, M.A.; Young, S.N.; Dean, P.; Palmour, R.N.; Benkelfat, C. Neuropsychopharmacology, 1996, 15, 465.

[54] Benkelfat, C.; Ellenbogen, M.A.; Dean, P.; Palmour, R.M.; Young, S.N Arch. Gen. Psychiatry, 1994, 51, 687.

[55] Booij, L.; van der Does, W.; Benkelfat, C.; Bremner, J.D.; Cowen, P.J.; Fava, M.; Gillin, C.; Leyton, M.; Moore, P.; Smith, K.A.; van der Kloot, W.A. Neuropsychopharmacology, 2002, 27, 852.

[56] Klaassen, T.; Riedel, W.J.; van Someren, A.; Deutz, N.E.; Honig, A.; van Praag, H.M. Biol. Psychiatry, 1999, 15, 489.

[57] Riedel, W.; Klaassen, T.; Schmitt, J.A. Brain Behav. Immun., 2002, 16, 581 [58] Riedel, W.; Sobczak, S.; Schmitt, J.A. Adv. Exp. Med. Biol., 2003, 527, 207.

[59] Evers, E.A.; Cools, R.; Clark, L.; van der Veen, F.M.; Jolles, J.; Sahakian, B.J.; Robbins, T.W. Neuropsychopharmacology, 2005, 30, 1138.

[60] Rubia, K.; Lee, F.; Cleare, A.J.; Tunstall, N.; Fu, C.H.Y.; Brammer, M.; McGuire, P. Psychopharmacology (Berl.), 2005, 179, 791.

[61] Evers, E.A.; van der Veen, F.M.; van Deursen, J.A.; Schmitt, J.A.; Deutz, N.E.; Jolles, J. Psychopharmacology (Berl.), 2006, 187, 200.

[62] Horacek, J.; Zavesicka, L.; Tintera, J.; Dockery, C.; Platilova, V.; Kopecek, M.; Spaniel, F.; Bubenikova, V.; Hoschl, C. Physiol. Res., 2005, 54, 235

[63] Morgan, R.M.; Parry, A.M.; Arida, R.M.; Matthews, P.M.; Davies, B.; Castell, L.M. Psychopharmacology (Berl.), 2007, 190, 383

[64] Allen, P.P.; Cleare, A.J.; Lee, F.; Fusar-Poli, P.; Tunstall, N.; Fu, C.H.; Brammer, M.J.; McGuire, P.K. Psychopharmacology (Berl.), 2006, 187, 486.

[65] Ruhé, H.G.; Mason, N.S.; Schene, A.H. Molecular Psychiatry, 2007, 12 331 .

[66] Young, S.; Smith, S.E.; Pihl, R.O.; Ervin, F.R. Psychopharmacology (Berl.), 1985, 87,173 .

[67] Smith, S.E.; Pihl, R.O.; Young, S.N.; Ervin, F.R. Psychopharmacology (Berl.), 1987, 91, 451.

[68] Beats, B.; Sahakian, B.J.; Levy, R. Psychol. Med., 1996, 26, 591.

[69] Elliott, R.; Sahakian, B.J.; Herrod, J.J.; Robbins, T.W.; Paykel, E.S. Journal of Neurology, Neurosurgery and Psychiatry, 1997, 63, 74.

[70] Murphy, F.C.; Michael, A.; Robbins, T.W.; Sahakian, B.J. Psychological Medicine, 2003, 33, 455 .

[71] De Bruijn, E.; Hulstijn, W.; Verkes, R.J.; Ruigt, G.; Sabbe, B.G. Psychopharmacology (Berl.), 2004, 177, 151.

[72] Coull, J.T.; Sahakian, B.J.; Middleton, H.C.; Young, A.H.; Park, S.B.; McShane, R.H.; Cowen, P.J.; Robbins, TW. Psychopharmacology (Berl.), 1995, 121, 222.

[73] Rowley, B.; Van, F.; Mortimore, C.; Connell, J. J. Psychopharmacol. (Oxford), 1997, 11, A60.

[74] Rosse, R.B.; Schwartz, B.L.; Zlotolow, S.; Banay-Schwartz, M.; Trinidad, A.C.; Peace, T.D.; Deutsch, S.I. Clin. Neuropharmacol., 1992, 15, 129.

[75] Sobczak, S.; Riedel, W.J.; Booij, L.; Aan Het Rot, M.; Deutz, N.E.; Honig, A. Psychol. Med., 2002, 32, 503 .

[76] Berridge, K.C.; Robinson, T.E. Brain Res. Rev., 1998, 28, 309.

[77] Berridge, K.C. Psychopharmacology (Berl.), 2007, 191, 391.

[78] Dayan, P.; Balleine, B.W. Neuron, 2002, 36, 285.

[79] Göthert, M.; Ann. N. Y. Acad. Sci., 1990, 604, 103

[80] Alex, K.D.; Pehek, E.A. Pharmacol. Ther., 2007, 113, 296.

[81] Hood, S.; Bell, C.J.; Nutt, D.J. Aust. N. Z. J. Psychiatry, 2005, 39, 558

[82] Booij, L.; van der Does, A.J.; Haffmans, P.M.; Riedel, W.J.; Fekkes, D; Blom, M.J. J. Psychopharmacol., 2005, 19, 267.

[83] Young, S.; Ervin, F.R.; Pihl, R.O.; Finn, P. Psychopharmacology (Berl.), 1989, 98, 508 .

[84] Carpenter, L.L.; Anderson, G.M.; Pelton, G.H.; Gudin, J.A.; Kirwin, P.D.; Price, L.H.; Heninger, G.R.; McDougle, C.J. Neuropsychopharmacology, 1998, 19, 26.

[85] Lieben, C.K.; Blokland, A.; Westerink, B.; Deutz, N.E. Neurochem. Int. 2004, 44, 9 .

[86] Abbott, F.V.; Etienne, P.; Franklin, K.B.; Morgan, M.J.; Sewitch, M.J.; Young, S.N. Psychopharmacology (Berl.), 1992, 108, 60.

[87] Dibbets, P.; Bakker, K.; Jolles, J. Neurocase, 2006, 12, 71.

[88] Wilkinson, D.; Halligan, P. Neuroscience, 2004, 5, 67.

[89] Van der Veen, F.M.; Evers, E.A.; Deutz, N.E.; Schmitt, J.A. Neuropsychopharmacology, 2007, 32, 216.

[90] Rogers, R.D.; Everitt, B.J.; Baldacchino, A.; Blackshaw, A.J.; Swainson, R.; Wynne, K.; Baker, N.B.; Hunter, J.; Carthy, T.; Booker, E.; London, M.; Deakin, J.F.; Sahakian, B.J.; Robbins, T.W. Neuropsychopharmacology, 1999, 20, 322 . 